\title{
FINANCING THE ACQUISITION OF SURPLUS PLANTS AND GOODS
}

\author{
David L. PodelL*
}

\section{INTRODUCTION}

It has apparently become quite fashionable in certain circles indiscriminately to condemn the Surplus Property $\mathrm{Act}^{1}$ as cumbersome, visionary and impractical. Certain industrialists, publicists, and even some government officials, have gone so far as to ridicule what they describe as its high-sounding objectives, impossible provisions for priorities and preferences, and unbusinesslike approach to the whole problem. Some pamphleteers have pointed to alleged scandals and laid them at the door of the Congress with the refrain, "I told you so."

To many of these critics the disposal of government surplus is simply a business proposition. Their formula is clear-cut and direct. Sell your surplus at the highest possible market price and whatever threatens to glut the market, load into surplus bottoms, choose a desirable and secluded spot somewhere in mid-ocean, and give it quiet burial. The probability is that few of these critics have bothered about reading the Act, and still fewer about giving that law the consideration and study it deserves.

The truth of the matter is that scarcely any sales have as yet been made under the provisions of the Act. The Surplus Property Board created by the Act has but recently begun to function and at this writing has issued its first three or four regulations ${ }^{2}$ which relate to $(\mathrm{I})$ designation of disposal agencies and their reporting

* A.B., 1905, LL.B., I907, Columbia University. In law practice, New York City, 1907-1942. Retired from private practice 1942. At various times Special Assistant to the Attorney General in AntiTrust activities. Became General Counsel of Smaller War Plants Corporation in 1944. Member: American Bar Association, New York State and County Lawyers Association, Trade and Commerce Bar Association. Contributor to legal periodicals.

${ }^{1} 58$ STAT. 766 , 50 U. S. C. A. App. (1944) \$I6ri et seq.

2 Surplus Property Board Regulation No. I, Io Fed. REg. 3764 (1945), as amended 10 id. 4356 (1945); Regulation No. 2, 10 id. 5108 (1945). See also Temporary Regulation A, relative to forcign disposal, ro id. 2129 (1945). During the lapse of time since this article was originally drafted and galley proofs (May-July, I945), the Board issued a series of regulations dealing with the following subjects: Dispositions of Surplus Property in Rural Areas and to Farmers; Disposal of Surplus Acronautical Property to Educational Institutions for Non-Flight Use; Surplus Non-Industrial Real Property; Sale of Government-owned Plant Equipment in Contractor's Plants; Preferences for Veterans; Forcign Disposal; and Contractor Inventory and Disposals by Owning Agencies. SPB Regulations Nos. 3 to 9, inclusive: I0 F.R. 5325; 5460, 5603, 6785; 6252, 7500; 6309, 6981; 6519; 7118; 7413 (1945).

These regulations carry out fundamental objectives of the Act and in doing so, indicate that the approved policies of the Board follow along these lines: facilitation of acquisition by farmers of surplus equipment suitable for farm use, particularly trucks, machinery and equipment, whenever shortages threaten farm production; transfers of aeronautical equipment for non-flight use to benefit students in 
procedures; (2) foreign disposal; and (3) priorities of government agencies and state or local governments. Hundreds of millions of dollars worth of surplus had been disposed of under the regulations adopted by the Surplus Property Administrator long before there was any Surplus Property Act. ${ }^{3}$. In addition, the Services have sold large quantities of termination inventory, scrap and salvage running into many millions of dollars. In this initial period of operation under Executive Order of the President, a practical, successful businessman was the Administrator, who added to his wide experience and unquestioned competence an earnest desire to do a thorough and creditable job of surplus disposal:

The Congress, emphasizing the far-reaching social-economic implications, declared them to be paramount, and charted a course which, if properly pursued by the Board, should convert a challenge into an opportunity and an opportunity into a national boon beneficial to all our people, particularly during the reconstruction period. It did not wish to repeat the mistakes and experience of the last war.

\section{SURPLUS IN WORLD WAR I}

Congress did not make adequate studies or provide any planned approach to the problem of surplus property disposal either during or at the end of World War I. In his annual report for I920, the Secretary of War stated that "nowhere in the world at any time" had there been a commercial problem "comparable in extent or intricacy."4 Between I9r8 and I926, approximately 6 billion dollars of

non-profit educational institutions by stimulating aeronautical interest and knowledge; disposition of surplus real property, exclusive of industrial real property, airports, harbors, shipyards, port terminals, and power transmission lines, with emphasis on priorities set forth in the Act; promotion of effective distribution of Government-owned equipment in possession of Government contractors by favoring retention by such contractors, whether large or small. SWPC designated as agent for sales to veterans on top priority basis up to $\$ 2,500$; re-importation of foreign surplus prohibited; and notice of competitive sales of contractor inventory by publication in newspapers of general circulation to promote speedy and equitable disposition.

${ }^{8}$ The Surplus Property Act was approved on October 3, r944. The Surplus War Property Administrator previously set up by Executive Order 9425, 9 FED. REG. 207I (1944), was to be superseded, under the provisions of the War Mobilization and Reconversion Act after two members of the Surplus Property Board had taken office. 58 StAr. 785, 50 U. S. C. A. App. (I944) \$165I(b). One member, Governor Robert A. Hurley, took office on December 22, 1944. The second member, Col. Edward H. Heller, took office on January 2, r945. The first Chairman, Senator Guy M. Gillette, took office on January 19, 1945. While some provisions of the Act became immediately effective, certain others required implementation in the form of new regulations to replace those carried over from the Surplus War Property Administrator. Between February 19, 1944, and December 16, 1944, the Surplus War Property Administrator, appointed by the President, sold surplus pursuant to Executive Order 9425 and regulations issued thereunder. For a report on total disposals by Federal agencies (involving property with a cost or appraised value of 519 million dollars) during the first seven months of operation under SWPA Regulation No. I, June-December r944, see SPB, Monthly Progress Report, Dec. I944 (dated Jan. 3I, 1945).

For an official announcement as to the effect of the Surplus Property Act upon continuance of existing procedures and operations pending appointment of Surplus Property Board and issuance of regulations by it, see JoINT StATEMent, Nov. I5, I944, by the heads of the principal government agencies concerned with disposal of surplus property (War Department, Navy Department, Treasury Department, Maritime Commission, RFC, FEA, WFA, and SWPA).

- See Disposal of Surplus War Materiazs: Policies and Procedures, i9i8-ig26 (study prepared by the Bureau of Labor Statistics), Senate Subcommittee Print No. 7, 78th Cong., 2d Sess. (Sept. 25, 1944), the same being a "Report of the Senate Military Affairs War Contracts Subcommittee, pursuant 
surplus materials and facilities were sold in this country and abroad. The recovery percentage (i.e., ratio of selling price to cost value) for property sold in the United States averaged one-third of its cost.

Legislation vested plenary surplus disposal powers in the President who, in turn, delegated authority to heads of executive departments as he deemed expedient. At first, surplus property disposition was conceived as primarily the function of the War Department. Widespread public complaints and charges arose against the lack of coordination in declaring surpluses, holding consumers' goods off the market, failing to make inter-agency transfers of necessary equipment, unconscionable profits of middlemen, and other objectionable phenomena generated by chaotic government control and haphazard handling of a vital problem. Congressional investigations followed which revealed shortcomings of administration. An attempt at patchwork legislation gradually evolved.

By November, 1923, fifty-seven different laws had been enacted authorizing disposition of surplus property. During the fifteen-month period following February, IgIg, eleven acts were approved providing for transfer of general and special materials from the War Department to other agencies. Recognition of the need for an integrated procedure, coordinated with declared over-all social and economic objectives, was significantly lacking in these statutes. The problem was viewed from a purely commonplace standpoint dictated by the mere necessity of getting the job done-without striving for such goals as protecting the competitive opportunity of small enterprise, curbing the effects of monopoly, or facilitating an organized, well-balanced transition into the reconversion and postwar period. Every effort was made to consummate cash sales. Legislation did not exist authorizing financial assistance in connection with small lot or other purchases by veterans, mediumsized concerns, or farmers, either by government loans, guarantees, leases, long-term credits, or other means. Small business was left to shift for itself. It did not have a legislatively designated and empowered representative.

Improvisation characterized this planless era of surplus disposal, which even included random experiment with direct government selling through seventy-seven retail stores operated by the Quartermaster. Attempts at more centralized control resulted eventually in the creation of such bureaus and functionaries as the Director - of Sales, Surplus Property Division, and Surplus Property Committee, which were succeeded by the Office of Chief Coordinator, with a Liquidation Section and Aides for Liquidation, and finally by the Federal Liquidation Board which continued in existence until 1929.5

to S. Res. 198." Pages 1 to 7 summarize the history of surplus property administration from 1918 to 1926. Pages y09 to 118 set forth complete statistics on disposal sales with a full breakdown according to categories.

${ }^{5}$ See statement of Wendell Berge, Assistant Attorney General of the United States, on April 25, 1945 before the Senate Small Business Subcommittce on Surplus Property on disposal of machine tools after World War I. 


\section{Objectrves of Surplus Property Act of i944}

In contrast to this groping along without discernible social purpose, the Surplus Property Act of 1944 represents a carefully designed piece of legislation into whose fabric important principles of national policy have been prudently woven. While the Act may be far from perfect, some of its primary objectives, as distinguished from the cold "businesslike" approach, strike at social evils universally recognized, and point the way to methods of disposal which, always subject to proper administration, will tend to preserve the American way of life.

They may be stated as follows:

(I) A mandate to avoid hoarding, concentration of scarce goods in the hands of a few, and monopolization.

(2) To afford the ten million or more veterans an opportunity to re-establish themselves in business, agriculture or professional enterprises.

(3) To ban speculation and speculators who render no useful service.

(4) To secure wide and equitable distribution of property that is in scarce supply.

(5) To foster the development of new, independent enterprises.

(6) To foster and develop postwar employment opportunities, as well as foreign markets.

(7) To develop family-type farming.

(8) To strengthen and preserve the competitive position of small business.

(9) To utilize normal channels of trade and commerce-consistently, however, with the promotion of the general objectives of the Act, and without discrimination against new enterprises.

The last provision in the Act's declaration of objectives is rather significant: "Except as otherwise provided, to obtain for the Government, as nearly as possible, the fair value of surplus property upon its disposition." 6

\section{Small Business}

Operations thus far under the Act have been limited in volume but a case in point may already be cited as illustrative of the approach of the Board.

A medium-sized manufacturer desired to acquire a small surplus plant in a midwestern city, particularly suitable to his needs. In his effort to purchase the property, he found himself in competition with a nationally-known institution dominant in its industry. His initial bid was $\$ 221,000$, which was in excess of cost or appraised value. Bidding was lively, and the larger institution offered as high as $\$ 230,000$. The small manufacturer declared he would meet that top price, but that he was convinced that his competitor was determined to secure the property and prepared to outbid any figure he might offer.

Here was an opportunity for an efficient, businesslike administrator to capitalize on the contest and enrich the government with additional profits. However, the Smaller War Plants Corporation presented the situation to members of the Surplus

\footnotetext{
${ }^{0}$ Sec. $2(t)$ of the Act, 58 Star. 766, 50 U. S. C. A. App. (1944) §I6II(t).
} 
Property Board, who, acting in the spirit of the law, advised that the disposal agency make the sale to the smaller manufacturer at the price of $\$ 230,000$.

It may reasonably be expected that in the attempted sale and disposal of about fifteen billion dollars worth of plants, large and small, situations of this type will frequently present themselves. The position taken by the Board was nothing more or less than a tangible expression of the spirit of the surplus law."

An entire section of the law is devoted to the protection of the interests of small business enterprises (Section 18 ). The Board is directed to devise means for preventing discrimination against small business in the distribution of surplus. The Smaller War Plants Corporation is required to make nation-wide surveys, consult with small business as to their needs, report to the disposal agencies, and, where necessary, in cooperation with them, arrange for sales on a time or credit basis. The Corporation is also authorized to purchase out of surplus for purposes of resale to small business. In the exercise of that authority, it can purchase on the same priority basis as a Federal agency buying for its own use. Finally, and perhaps most important, it is empowered to finance "the acquisition, conversion and operation of plants and facilities which have been determined to be surplus property" [Section $\mathrm{I} 8(\mathrm{f})]^{7}$

\section{Prtorities and Preferences}

Perhaps the favorite target for critics of the Act is to be found in the provisions for priorities. ${ }^{8}$ The charge is made that they render the Act unworkable. They object that special consideration is being extended to (a) Federal agencies; (b) state, local and non-profit institutions; (c) veterans; (d) small business; (e) familytype farmers; and (f) prior owners of real property requisitioned by the government.

It scarcely requires argument to justify the special considerations extended in each of the above categories. Indeed, no attempt is made even by the most outspoken of the critics to argue the contrary. Few would deny the right of the returning veteran to a preference. For a Federal agency not to be allowed first call on surplus property would be comparable to an individual who performs the idle

ea The Board's statement of official policy, issued on July 4, 1945 , in regard to disposition of Government-owned plants to small concerns, gave unequivocal recognition to the desirability of encouraging their expansion as a part of our system of free competitive enterprise. It declared: "The Surplus Property Act of 1944 requires the Board to obtain fair value for surplus property rather than the highest price obtainable. It is the policy of the Board that insofar as possible Government-owned plants, and especially medium-sized and small plants, be sold or leased to local and small rather than national and large concerns. ... The disposal agency should accept an offer from a responsible local group with adequate working capital and know-how, even if extended credit over a period of years up to 90 percent of the purchase price is necessary, rather than an equal cash offer from a . . a group which would tend to concentrate economic power. [The disposal agency] should also, in consultation with the Board, scriously weigh lower offers ... eminating from local groups if it appcars that the American system of free competitive enterprise will benefit thereby. It should be especially vigilant against accepting offers which may result in the closing of plants by purchasers who would wish to prevent healthy competition."

${ }^{7} 50$ U. S. C. A. App. (1944) $\S 1627(f)$.

Sections 12, 13, I6, I7, I8 and $23(\mathrm{~g})$ of the Surplus Property Act, 50 U. S. C. A. App. (1944) \$1 $1621,1622, x 625,1626,162 \%, x 632(\mathrm{~g})$. 
and costly ceremony of selling the very article he requires, only to repurchase it later for his own use at a higher price.

Who would deny a hospital, public school or similar institution the right to acquire urgently needed articles which are short in supply, and perhaps cannot be acquired in the public market?

Who would deny the prior owner of lands or buildings which have been taken from him by eminent domain under the pressures of war, when he is eager to reacquire them, at fair prices, on termination of hostilities?

Certainly we should not favor the disposal of surplus lands in huge bulk, possibly to speculators, as against a policy of satisfying a widespread demand for sales to individual farmers who will themselves operate those farms.

Finally, in connection with such special consideration as is extended to small business, there is this to remember-most of our giant institutions operating government plants and equipment have protected themselves by securing options to purchase. They have first call to acquire what, at least for a time, will be critically scarce materials, implements, and even plants themselves. It is unnecessary here to mention the numerous other advantages which an institution, dominant in its industry, has enjoyed in the war period. A painful reminder, indeed, is the disclosure made in the first year of the war that fifty of our giant industrial concerns had been awarded 76 percent of the war contracts in dollar volume. We are often reminded that in two years of the war there were over a half million unlisted casualties among small business concerns, all of which had impelled the Congress first to create the SWPC, ${ }^{9}$ and thereafter, to constitute that corporation as the guardian of small business interests. ${ }^{10}$ The stated objectives of the Act would indeed have been empty, high-sounding phrases if they had not been implemented by these specific provisions giving special consideration to those categories. ${ }^{11}$

\footnotetext{
- The Smaller War Plants Corporation was created by the Small Business Mobilization Act, June II, 1942. 56 STAT. $35 \mathrm{I}$, 50 U. S. C. A. App. (I944) $\$ \mathrm{IIO}_{4}$, with power (I) to assist and finance small business concerns engaged in war and essential civilian production, either by loans and guarantees or leases of machinery and equipment; and (2) to certify to government procurement agencies as to the competency of qualified smaller plants as prime or subcontractors, or to take a direct government prime contract itself for the purpose of spreading subcontracts among smaller plants. The legislative history indicates that Congress clearly recognized that the concentrated distribution of procurement contracts during the first year and a half of the present war illustrated a pressing need for a separate government agency to represent smaller concerns. See Hearings before subcommittee of Committee on Banking and Citrrency on S. 2250, 77th Cong., 2d Sess. (1942) parts I and 2, passim; (H. R.) Hearings before the Committee on Banking and Currency on S. 2250 and H. R. 6975, 77th Cong., 2d Sess. (I942) passim; H. R. REP. No. 2131, 77th Cong., 2d Sess. (1942).

10 In addition to the functions granted it by the Surplus Property Act, SWPC became the legislatively designated representative of small business under related reconversion statutes, e.g., see Sections $3(\mathrm{~g})$, 5, $20(\mathrm{~g})$, and $21(\mathrm{~b})$ of the Contract Settlement Act of 1944, approved July I, I944, 58 STAT. 649, 4I U. S. C. A. (Supp. 1944) §10I et seq., and Sections 204 and 601 of the War Mobilization and Reconversion Act of 1944, approved October 3, 1944, 58 STAT. 785,50 U. S. C. A. (1944) \$1651 et seq. Both Sen. Rep. No. 1057, 78th Cong., 2d Sess. (Aug. 22, 1944) 9-1o and H. R. REP. I89o, 78th Cong., 2d Sess. (Sept. 14, I944) 26-27, App. (the Senate and Conference Reports on the Surplus Property Bill), deal pointedly with the subject of small business.

${ }^{12}$ The Third Report of the Attorney General (dated April 24, 1945) to the Congress, pursuant to Section 205 of the War Mobilization and Reconversion Act of 5944 (Dep't of Justice, Advance Release, 12:00 noon, April 24, 1945) contains an able presentation of the underlying objectives of the Surplus
} 
But it is said they render the Act unworkable. To jump to a conclusion of that character-even before the Board has had a chance to draft the necessary regulations and has tested them in practice, before there has been anything approaching a fair trial-certainly does not do credit to the ability, or capacity, or competency of the disposal agencies, the Surplus Property Board, or any of the government instrumentalities involved in disposal.

These preferences or priorities are to be made applicable to a diverse variety of real and personal property, in most cases peculiarly adaptable to one or the other of the various categories. The farmer will want to buy land and agricultural implements. The small business concern will require raw materials, and machinery and equipment. The requirements of the veteran will vary with the particular business, profession or occupation in which he engages.

In these days of scarcity, it is simple justice to pursue a policy of the widest possible distribution, and if there is not enough to satisfy all demands, let those that are clearly entitled to it receive special consideration. These priorities and preferences can only be of value when the supply is short. The likelihood is that at least until V-J Day, and possibly for several months thereafter, there will be an insufficient supply of innumerable commodities to satisfy all demands. We are far from the stage where we need be concerned about glutting any markets, except possibly in aircraft and certain war products.

\section{Financing Acquisition of Surplus Generaliy}

Facilities for financing the acquisition of surplus vary to some extent with the type of goods or property sought to be acquired. Under the Small Business Mobilization Act of 1942, SWPC was granted broad authority for financing the construction and acquisition of plants, machinery, equipment, materials and supplies for the manufacture of articles to be used for war or essential civilian purposes. ${ }^{12}$ No authority was given to make loans or guarantees for those engaged in the fields of service or distribution, or any profession or other occupation not falling within the category of production. The Surplus Property Act has granted authority to make loans and guarantees to small business concerns engaged in any field of activity in order to facilitate their acquisition of surplus property.

In the case of plants and facilities, i.e., capital and durable goods, the authority to finance is about as broad as it could be written. The language of the Act author-

Property Act. It declared: "It is significant that both the Surplus Property Act and the War Mobilization and Reconversion Act express, emphatically and repeatedly, a freely competitive, anti-monopolistic, and pro-small business philosophy (p. 15)." "The Surplus Property Act shows a clear realization that the disposal of surplus property involves much more than merely an attempt to get the best price for the Government or to sell the property to the highest bidder. Most of the 'objectives' found in the Act are not in terms of original cost, or any regulated discount on cost, but in terms of full utilization in order to provide maximum employment and economic opportunity. The property to be sold could well be called opportunity rather than surplus property. It will become surplus only when American resourcefulness fails to find for it a constructive peacetime use" (p. 20).

${ }^{12}$ For legislative history pertaining to the creation of Smaller War Plants Corporation, sce citations supra, note 9 . 
izes SWPC "to make or guarantee loans to small business enterprises in connection with the acquisition, conversion and operation of plants and facilities which have been determined to be surplus property."

With respect to consumer goods, the Corporation is authorized "in cooperation with the disposal agencies, to arrange for sales of surplus property to small business concerns on credit or time bases."

As to all surplus property, SWPC is authorized to purchase out of surplus for purposes of resale to small business concerns and, if necessary, to exercise its priority as a Federal agency for the acquisition of this surplus as though it were buying for its own use.

Representatives of SWPC, having in mind the history of the Act, have stated repeatedly, both as a matter of record before legislative committees, as well as on other occasions, that it is neither the intention nor desire of the Corporation to go into the surplus business as such. Translated into operation, this declaration means that, except where it is unavoidable, the Corporation will not indulge in storage or stockpiling or merchandising. Its primary aim will be to make certain that small business concerns have a fair opportunity to acquire surplus materials in the following order of importance:

(I) Machinery and machine tools.

(2) Raw materials necessary for the conduct of their business.

(3) Plants and facilities, either jointly as part owners and operators, or as individual lessees, or as part of a group for multiple tenancy.

(4) Such other consumer goods as may be required in the conduct of their business.

The Corporation is likewise planning to furnish its financial and other facilities to satisfy the requirements of veterans.

\section{Durabie Goods}

Inquiries of the Corporation have disclosed that the vast majority of small plants of the nation are operating with machinery and equipment which is anywhere from I5 to 30 years old, the greatest portion of it rendered obsolete by modern improvements and inventions, especially during the war period. Renovation of these plants will result in increased efficiency of production, reduced expense of operation, better service to the public, better production, and decreased hazard to the employees. From the point of view of strengthening small business and preserving its competitive position, one of the prime declared objectives of the Surplus Property Act, it would be difficult to conceive of a more urgently needed service.

Since the Act does not limit SWPC's authority to facilitate acquisition of surplus property only to those engaged in production, such a service would redound to the benefit of some 630,000 service establishments including garages, laundries, repair shops and the like. The distributor would be equally free to acquire better and improved types of machines. Likewise, the veteran who desires to undertake any profession or business would be able to secure the necessary equipment. 
To facilitate this process of re-equipment and modernization of the production, service and other industries, the Surplus Property Act has specifically provided that SWPC may accept in partial payment the old equipment being replaced.

Financing of these purchases may take the form of (a) a sale by the disposal agency on a credit or time basis; (b) an outright loan by SWPC at a 4 percent interest rate to be repaid in installments within a period not exceeding five years; (c) a purchase by SWPC with a resale on a time or credit basis; and (d) a leasing arrangement for a period of years at a stated rental.

Within the past two and a half years, SWPC has financed the acquisition of machinery for war or essential civilian production running into many millions of dollars. The Corporation therefore has the necessary field and national office set-up and experience for making loans and leases of machinery and equipment to small concerns. ${ }^{13}$

A preliminary survey indicates a wide and active demand for machine tools and other equipment. Despite the outstanding options running to our leading business institutions and covering all types of machinery and equipment, it is expected that in the course of time there will be more than an ample supply in surplus to satisfy the requirements of small plants. Financing these acquisitions should present little difficulty.

It is exceedingly important, however, that small businessmen exercise sound judgment in determining the type of machine they can best utilize, and make that requirement known so that the item may be speedily located in surplus.

\section{Consumer Goods}

The hypothecation of consumer goods to support financing of their acquisition presents a real difficulty. Since local laws governing hypothecation of consumer or movable goods may vary in the several states and frequently prohibit the pledging of an effective lien, other techniques will have to be developed to protect the government's credit advances. Warehouse and trust receipts may be of value in certain jurisdictions, but in the last analysis, some reasonably adequate collateral will have to be supplied to warrant the credit risk of government funds, or the applicant be required to show a reasonable credit status. Government loans to acquire consumer goods for personal use would scarcely be justified. Government loans to replenish the stock of a wholesaler or retailer might, in certain exceptional situations, be proper where the financial condition of the purchaser furnishes reasonable assurance of repayment, or he can otherwise demonstrate that he is a reliable credit risk. Greater liberality might well be exercised in setting up a veteran in business.

Experience of the Corporation has shown that it is eminently desirable to conduct financing operations through the medium of a local bank which can service

${ }^{13}$ In his statement on April 27, x945, before the Senate Small Business Subcommittec on Surplus Property, on the problem of machine tool disposal, Maury Maverick, Chairman of SWPC, declared that the Corporation had made loans and leases of machinery and machine tools to smaller war plants aggregating $\$ 34,800,000$. 
the loan for a reasonable compensation and be guaranteed by the government agency to the extent that the bank desires, its compensation being inversely proportional to the percentage of guarantee. Maximum interest rates should not exceed 4 percent.

Automotive equipment, trucks, automobiles, jeeps and peeps already have established methods of financing which may readily be applied by any government agency (without the oft-times excessive interest and other charges)-all of which will not only aid in the widest possible distribution, but also place acquisition within reach of the farmer, veteran, and small businessman.

Private financing should at all times be encouraged, perhaps with government guarantees, provided that the interest and other charges are kept within reason.

\section{Government War Plants and Factutties}

If the fundamental objectives of the Surplus Property Act are to be attained, the problems besetting the disposal of government war plants will center more in the social-economic sphere than in the field of financing. Strange as it may seem, financing probably presents the least difficulty, especially in the light of the magnitude and complexities of the other problems.

Prior to the war, the appraised value of all the plants of the country was roughly about 23 billion dollars. Since I939, the government has invested between $I_{5}$ to I7 billions of dollars in actual cost of plant facilities and equipment. These figures do not include private expansion and private construction.

It may be fairly inferred, even allowing for differentials in building costs and the quality and character of new structures, that plant capacity, including equipment, in this country has doubled since I939. Estimates place the total floor space of these new structures at approximately 430 million square feet-equivalent to ro,000 acres. More than half of this area is accounted for by plants having one million square feet and over.

A recent SWPC survey ${ }^{1-4}$ presented the following summary of plants by area classes:

Government-Owned Industrial Facilitites Expansion Summary of Plants by Area Classes

\begin{tabular}{|c|c|c|c|c|}
\hline Area in Sq. Ft & $\begin{array}{c}\text { Million } \\
\text { Sq. Ft. } \\
\text { Area, } \\
\text { Bldgs. }\end{array}$ & $\begin{array}{c}\text { Percent } \\
\text { Total } \\
\text { Area }\end{array}$ & $\begin{array}{c}\text { No. } \\
\text { Plants }\end{array}$ & $\begin{array}{c}\text { Percent } \\
\text { Total } \\
\text { Plants }\end{array}$ \\
\hline $50,000 \ldots$ & I I.4 & 2.7 & 504 & 37.6 \\
\hline$-100,000 \quad \ldots$ & 13.4 & $3 . I$ & 179 & 13.4 \\
\hline $0-500,000 \quad \ldots$ & xот.6 & 23.8 & 439 & 32.8 \\
\hline $0-1,000,000$ & 70.9 & I6.6 & ro2 & 7.6 \\
\hline 000 and over & 229.5 & 53.8 & II5 & 8.6 \\
\hline otal & $4^{26.8}$ & 100.0 & I,339 & I00.0 \\
\hline
\end{tabular}

\footnotetext{
${ }^{14}$ Multiple Industrial Tenancy, a study prepared by the Office of Reconversion, Smaller War Plants Corporation, October 23, 1944 .
} 
Approximately one-half the number of plants are within the area class of roo,000 square feet or under. They comprise, however, less than 6 percent of the total plant area. If we go as high as the 500,000 area class, namely, plants about $500^{\prime} \mathrm{x}$ I,000 in dimension, we reach over I,I00 plants representing nearly 30 percent of the total floor area. These plants for the most part are located in the vicinity of populous communities and the larger cities.

Proper treatment of the plant disposal problem would seem to suggest a broad division into two categories: ( $I$ ) those whose size and area space hold forth some promise of normal commercial utilization; and (2) those of enormous size, scarcely suitable for any firms except those of the first magnitude. The dividing lines have been variously drawn, some at the 500,000 square feet area, and others at the $1,000,000$ square feet area. The latter would embrace a plant of $\mathrm{I}, 000^{\prime} \times \mathrm{I}, 000^{\prime}$.

Because of the lag in construction during the war period for civilian commercial use, and the accumulated demand, there would seem to be a fair prospect that normal-sized plants will lend themselves to disposal by lease or sale. The real difficulty arises in the limited demand for huge establishments with an area space comprising millions of square feet, usually of single-story construction, designed and built for a specific war purpose at high cost.

The Attorney General, in a recent report to the Congress, has urged the advisability of disposing of such plants by lease rather than by sale. ${ }^{15}$ The interested parties will then have an opportunity to determine realistically the possibilities for adequate utilization and value for peacetime production, and at the same time the plants will not stay idle.

Such a policy, however, is not always an unalloyed blessing. In the case of hugesized plants, tenants can scarcely be ousted on short notice and the government can ill afford to brush aside an opportunity for a ready sale either to a group for purposes of multiple tenancy, or to a growing young entrepreneur who shows promise of probable success in his competitive enterprise. Then, too, a lease is apt to tie up the property for a period of several years-with the possibility that existing backlog of demand for space may well be dissolved and conditions so subtsantially changed that neither the local community, lessee, nor prospective purchasers would longer be interested.

These over-sized plants, as a group, scarcely lend themselves to the formulation of rigid policy. Each is in a different locality, of different shape and dimension, constructed for its own specific purpose, has varying amounts of usable space, and as a piece of real estate, is subject to the peculiar local conditions prevailing in the plant-site region. Each is a prima donna in its own right. While, in the one case, a leasing arrangement would appear to be most desirable, in the other an outright sale may be much the wiser course. Having in mind the social value as paramount, there should certainly be no rigidity in price formula, or for that matter in any of

${ }^{16}$ Third Report of the Attorney General, supra note II, at 22-24. 
the essential terms and conditions of sale, especially in amortization or interest rate. A basic essential is flexibility.

It must be borne in mind also, that under the Surplus Property Act the Armed Services have the right to determine which plants shall be reserved for their own use. That fact, however, need not delay early negotiations looking toward ultimate disposition. Agreements for that purpose, subject to conditions, can be entered into and Defense Plant Corporation (a subsidiary of RFC charged by the Board with responsibility for plant disposal) has approximately 200 such negotiations in progress. The only danger inherent in such procedure is the preference that would ensue to the occupant. The right of outsiders to bid should be carefully preserved and safeguarded.

Under the Act the government is at least as much concerned with proper utilization, increased production, maximum employment, and other social-economic opportunities, as it is with price and terms of sale. It certainly will serve no useful public purpose to install an entrepreneur in one of these plants if a reasonable prospect of successful operation is nowhere in sight, even though the government may recover its full cost. Nor should government property be sacrificed solely because of the probability of successful operation by a private entrepreneur. Since the government is the owner and vendor, the burden of maintenance, operation and amortization of purchase price can be adjusted so that the enterprise will have a reasonable opportunity for success, and if successful, the government will not only provide a continuing source of employment but afford itself a sound prospect of fair recovery.

\section{Methods of Plant Disposal}

Interesting studies have been made of different methods of disposal which, if successful, should inure to the public benefit. These would include:

(A) Direct sale to a small business concern of a normal-sized plant on the basis of long-term amortization and a low interest rate. In order that current costs of operation shall not hamper prospects of a successful enterprise, both amortization and interest may be graduated, and also be made dependent on favorable progress of the entrepreneur.

(B) Joint ownership by members of a group interested in a particular business or industry who contribute their respective shares to the acquisition. They may avail themselves of cooperative economies, utilize common facilities and servicessuch as research laboratories, shipping and freight facilities, power, light and heat, and even common purchasing and distributing-the process being comparable to cooperative apartment ownership or tenancy. ${ }^{16}$

(C) Multiple tenancy programs, where private individuals, or a corporation, make the purchase and lease space to individual tenants, much in the style of the Amoskeag or Bush Terminal enterprises. ${ }^{17}$

\footnotetext{
${ }^{16}$ See Francis Chilson, Reconversion (Oct. 1944) Drug and Cosmetrc Industry.

${ }^{17}$ Multiple Industral Tenancy, supra note 14 , at $4,5$.
} 
The joint or group effort, whether in one form or another, offers several advantages for effecting economies and increasing efficiency of production and public service. The larger the plant, the greater the flexibility for expansion or adequate adjustment.

Government financing may follow one of several courses:

(I) The disposal agency (RFC in the case of industrial plants) may adjust the terms and conditions of sale with a view to successful operation, in which case longterm credit factors and low interest rates would be of inestimable value; or

(2) SWPC may acquire the plant and facilities for resale, in which event it is authorized to make loans and guarantees to facilitate not only acquisition but conversion and even operation of the property [Section $18(f)]$; or

(3) SWPC actually finance acquisition from the disposal agency, and then conversion and operation; or

(4) Private banking or security financing which, under the Surplus Property Act might be coupled with a guarantee either from RFC or SWPC.

Regardless of the financing techniques found most appropriate in the particular case, it is essential that selling price be viewed realistically in terms of actual values represented by the properties. Here again flexibility is of the essence. Rigid formulas resting upon original cost or reproduction cost, or actual usable value determined by usable space available, or rental conditions of the local market, can scarcely be indulged or adopted as generally applicable to all sales of over-sized plants. Probably all of these standards plus several others, including the social-economic values of the enterprise, will have to be sexiously considered and very largely determined by a process of negotiation.

\section{ConcLusion}

The over-all job of surplus property disposition is of such magnitude, presents so many diverse and complex problems, that success can hardly be expected, even allowing for the utmost effort on the part of government, without the active cooperation and initiative of the average American businessman and the local communities where government plants are located.

It might be stated that facilities for financing the acquisition of surplus are ample. The disposal agencies have authority to make sales on credit or time bases. SWPC, specifically charged with guarding the interests of small business, not only has considerable experience and authority to finance, but the right to purchase for purposes of resale. Other government lending agencies can also exercise their finaneing powers to assist in surplus acquisition. Finally, normal channels, such as banks and other lending institutions, may supply necessary financing, and if the charges are not excessive, can obtain at least partial guarantees by government agencies. In the light of this situation, it may fairly be said that financing of surplus acquisition is probably among the least formidable of the difficulties involved. 
One of the primary objectives of the Act is to avoid the building of monopolies and further acquisition of sizable plants by dominant units of industry, a policy which found little opposition, or even dissent, in any quarter. This restriction affords an exceptional opportunity to small or medium-sized businesses for establishment, growth, and successful operation in modern quarters at probably considcrably reduced cost with the aid of government financing.

In his last annual message to Congress on January 6, r945, the late President Roosevelt mapped out a course for the postwar period looking toward full employment and expanding individual enterprise as integral parts of the American system of free competitive economy. He declared:

"We must make sure that private enterprise works as it is supposed to work-on the basis of initiative and vigorous competition, without the stifling presence of monopolies and cartels. During the war we have guaranteed investment in enterprises essential to the war effort. We should also take appropriate measures in peace time to secure opportunities for new small enterprises and for productive business expansion for which finance would otherwise be unavailable." 